\title{
A MULTIPROPRIEDADE IMOBILIÁRIA À LUZ DA LEI 13.777/2018
}

\section{THE REAL ESTATE MULTIPROPRIETY UNDER THE LAW 13.777/2018}

\author{
Cláudia Mara de Almeida Rabelo Viegas" \\ Rodolfo PAMPLONA FiLHO"*
}

\begin{abstract}
RESUMO
O ordenamento jurídico brasileiro consagra a propriedade como direito fundamental, desde que cumprida a sua função social, circunstância que pressupõe o aproveitamento otimizado do bem imóvel, recurso econômico escasso na sociedade pós-contemporânea. Nesse contexto, surge a multipropriedade imobiliária, relação jurídica que permite o compartilhamento da propriedade imóvel, por meio da aquisição de fração de utilização temporal do bem comum a vários sujeitos. $\mathrm{O}$ instituto, regulamentado no Brasil pela Lei ${ }^{\circ} 13.777$, de 20 de dezembro de 2018, concede aos titulares o exercício temporal fracionado, exclusivo, do direito de propriedade, exercido em período pré-determinado, renovado anualmente, de modo cíclico. Assim, por meio de técnica bibliográfica, quer se analisar as peculiaridades e os efeitos jurídicos da aquisição em sistema de multipropriedade no Brasil.
\end{abstract}

PALAVRAS-CHAVE: Multipropriedade. Time-Sharing. Condomínio. Fractional. Multiplicidade de sujeitos.

\begin{abstract}
The Brazilian legal system establishes property as a fundamental right, provided that it fulfills its social function, a circumstance that presupposes the optimized use of the property, a scarce economic resource in post-contemporary society. In this context, there is the real estate multipropriety, legal relationship that allows the sharing of immovable property, through the acquisition of a fraction of temporal use of the common good to various subjects. The institute, regulated in Brazil by Law No. 13.777, of December 20, 2018, grants the holders the exclusive fractional exercise of the right of ownership, exercised in a predetermined period, renewed annually in a cyclical manner. Thus, through a bibliographical technique, we want to analyze the peculiarities and legal effects of the acquisition in a multipropriation system in Brazil.

KEYWORDS: Multiproperty. Time-Sharing. Condominium. Fractional. Multiplicity of subjects.
\end{abstract}

SUMÁRIO: 1. Introdução 2. Conceito de Multipropriedade 3. Origem da Multipropriedade 4. A Natureza Jurídica da

* Professora de Direito da PUC Minas, Faculdade de Belo Horizonte, Conselho Nacional de Justiça e Polícia Militar. Coordenadora do Curso de Direito da Universidade Brasil - Faculdade de Belo Horizonte. Pós-doutoranda pela Universidade Federal da Bahia. Doutora e Mestre em Direito Privado pela Pontifícia Universidade Católica de Minas Gerais.

E-mail: claudiamaraviegas@yahoo.com.br.

* Professor Associado da graduação e pós-graduação (Mestrado e Doutorado) em Direito da UFBA - Universidade Federal da Bahia. Professor Titular de Direito Civil e Direito Processual do Trabalho da Universidade Salvador - UNIFACS. Mestre e Doutor em Direito das Relações Sociais pela PUC/SP — Pontifícia Universidade Católica de São Paulo. Juiz Titular da $32^{\text {a }}$ Vara do Trabalho de Salvador/BA. Máster em Estudios en Derechos Sociales para Magistrados de Trabajo de Brasil pela UCLM — Universidad de Castilla-La Mancha/Espanha.

E-mail: rpf@rodolfopamplonafilho.com.br 
Multipropriedade 4.1. Multipropriedade societária ou acionária 4.2. Multipropriedade real sobre coisa alheia 4.3. Imobiliária ou real 4.4. Multipropriedade hoteleira 4.5. A natureza jurídica da multipropriedade imobiliária adotada no Brasil 5. Peculiaridades e efeitos da Multipropriedade 5.1. O direito de preferência na multipropriedade 5.2. Efeitos do inadimplemento do multiproprietário 5.3. A possibilidade de incidência de gravames na unidade periódica 6 . Conclusão. Referências.

\section{INTRODUÇÃO}

A propriedade imóvel, fator determinante na formação das sociedades, é um dos mais importantes direitos reais elencados no art. 1.225 do Código Civil Brasileiro. Por se tratar de bem escasso na sociedade pós-contemporânea, persegue-se a utilização adequada da propriedade imóvel, de modo a atender os interesses privados e sociais, circunstância que leva o homem a otimizar a fruição de tal recurso econômico.

Exatamente, nesse contexto, surgiu o instituto da multipropriedade imobiliária, constituído pela possibilidade jurídica de repartir o exercício do uso e a fruição de um bem imóvel entre os coproprietários, durante período de tempo pré-fixado, sucessivo e proporcional à respectiva fração ideal temporal.

Fundado na noção de economia compartilhada, a figura jurídica que tem viabilizado empreendimentos de alto investimento, por meio da permissão do compartilhamento de imóveis, com uso em tempo proporcional ao investimento realizado.

$\mathrm{Na}$ prática, várias pessoas poderão ser proprietárias de um único imóvel de veraneio, com período de fruição exclusivo previamente definido pelos seus titulares, pagando apenas os custos temporais proporcionais ao seu quinhão.

Nessa situação concreta, a propriedade de um bem imóvel, muitas vezes inalcançável, na sua totalidade, em função do seu valor econômico, pode se tornar acessível pela técnica da aquisição temporal compartilhada, sobretudo, em face da diluição dos custos de aquisição e manutenção inerente ao sistema de multipropriedade.

O instituto tem sido utilizado, no Brasil, ainda de forma tímida, na viabilização de empreendimentos de hotelaria e casas de veraneio, nesse contexto, considerando a complexidade da convivência compartilhada de imóveis em multipropriedade, foi publicada, em 21 de dezembro de 2018, a Lei n ${ }^{\circ} 13.777$ com o objetivo de formular regras que tornem possível uma cooperação social ordeira nesse regime condominial.

Assim, por meio de pesquisa exploratória bibliográfica, quer se analisar as peculiaridades e os efeitos jurídicos da aquisição de bem imóvel em multipropriedade, à luz do novo diploma jurídico vigente no Brasil. 


\section{CONCEITO DE MULTIPROPRIEDADE}

A multipropriedade constitui uma noção moderna de aproveitamento de bens imóveis, que se diferencia da propriedade tradicional, especialmente, pelo fato de seus titulares adquirirem o poder de usar e gozar da coisa comum, de forma exclusiva, durante um período previamente fixado em registro.

Gustavo Tepedino, percussor do tema no Brasil, define a multipropriedade como sendo:

a relação jurídica de aproveitamento econômico de uma coisa móvel ou imóvel, repartida em unidades fixas de tempo, de modo que diversos titulares possam, cada qual a seu turno, utilizar-se da coisa com exclusividade e de maneira perpétua desde que se atinja a função social, qual seja, a utilização da propriedade de forma que não sirva apenas aos interesses individuais, mas que tenha como parâmetros também o interesse social ${ }^{1}$.

Com fito no aproveitamento econômico da coisa móvel e imóvel, o conceito denota uma relação jurídica que permite a divisão da propriedade, com utilização exclusiva para cada multiproprietário, em temporadas anuais, situação em que diversos titulares contribuem para a função social do bem.

A operação, fruto da autonomia privada daqueles que procuram alternativas para as crises econômicas, conquistou significativo espaço no mercado imobiliário mundial, sobretudo na Europa e nos Estados Unidos, tendo sido criado sob numerosos modelos jurídicos, cada qual com a sua natureza, peculiaridades que serão tratadas em tópico próprio a seguir.

Retomando-se o conceito de Tepedino, observa-se que o autor considera a possibilidade da instituição da multipropriedade em coisa móvel e imóvel. No entanto, a definição inserida no novo art. 1.358-C do CC, determinada pela Lei $\mathrm{n}^{\mathrm{o}} 13.777$, de 20 de dezembro de 2018, restringe a incidência do instituto aos bens imóveis, nos seguintes termos:

multipropriedade é o regime de condomínio em que cada um dos proprietários de um mesmo imóvel é titular de uma fração de tempo, à qual corresponde a faculdade de uso e gozo, com exclusividade, da totalidade do imóvel, a ser exercida pelos proprietários de forma alternada" ${ }^{2}$.

Nota-se que o legislador brasileiro optou por criar a multipropriedade, sob regime de condomínio especial, o qual permite a repartição da propriedade de um bem imóvel, em unidades temporais autônomas para cada proprietário, apresentando a periodicidade como fator essencial.

1 TEPEDINO. Gustavo. Multipropriedade imobiliária, São Paulo: Saraiva, 1993, p. 1

2 BRASIL. Lei $\mathrm{n}^{\circ}$ 13.777, de 20 de dezembro de 2018. Altera as Leis $\mathrm{n}^{\circ \mathrm{os}} 10.406$, de 10 de janeiro de 2002 (Código Civil), e 6.015, de 31 de dezembro de 1973 (Lei dos Registros Públicos), para dispor sobre o regime jurídico da multipropriedade e seu registro. Publicada DJE de 21/12/2018. Disponível em: < http://www.planalto.gov.br/ccivil_03/_Ato2015-2018/2018/Lei/ L13777.htm>. Acesso em 23 jan. 2019. 
Com efeito, o fator "tempo" diferencia a multipropriedade da propriedade tradicional em condomínio, especialmente, pelo fato de um dos titulares poder exercer exclusivamente durante um período pelo qual adquiriu o exercício temporal.

Segundo Caio Mário, há condomínio quando "a mesma coisa pertence a mais de uma pessoa, cabendo a cada uma delas igual direito sobre o todo e cada uma de suas partes" ${ }^{3}$. No ordenamento brasileiro, a relação condominial é regulada pelo art. 1.314 e seguintes do Código Civil.

Dessa forma, os condôminos possuem interesses qualitativamente iguais sobre a coisa, exercendo seu direito sobre a integralidade do bem, ainda que possua apenas uma fração ideal sobre o todo. Portanto, o direito de propriedade — que se manifesta pelo exercício do uso, fruição e disposição — é exercido ao mesmo tempo por todos os coproprietários da coisa.

A multipropriedade, a seu turno, fixa-se na possibilidade de repartir o exercício do uso e da fruição por cada um dos coproprietários, durante período de tempo pré-fixado, sucessivo e proporcional à fração ideal que possui.

Assim, entende-se por multipropriedade, o exercício temporal fracionado, exclusivo, do direito de propriedade comum a múltiplos sujeitos, exercido em período pré-determinado, renovado anualmente, de modo cíclico.

\section{A ORIGEM DA MULTIPROPRIEDADE}

Para se entender o instituto contemporâneo da multipropriedade imobiliária, propõe-se, inicialmente, uma breve revisitação das mutações da configuração da propriedade privada ao longo da história da humanidade.

A origem da propriedade é controversa, filósofos e teóricos se dividem, especialmente, em duas vertentes: os que defendem ser a propriedade um direito natural, que nasce com o indivíduo e independe do surgimento do Estado e aqueles que entendem que o direito de propriedade nasce somente como conseqüência do Estado.

As condições econômicas e políticas de cada época influenciaram diretamente na evolução histórica do instituto da propriedade, ou seja, o domínio do homem sobre a propriedade alterou-se, ao longo do tempo, em função das condições morais, jurídicas e econômicas, vividas por determinados grupos de indivíduos.

Sobre esse aspecto, Maria Vital da Rocha acentua que "o direito de propriedade, desde os tempos da Roma antiga, foi, paulatinamente, premido pela adaptação do seu exercício aos interesses da coletividade"4.

3 PEREIRA, Caio Mário da Silva. Instituições de Direito Civil. 18 ed. Rio de Janeiro, Forense, 2003. p. 175.

4 ROCHA, Maria Vital da. Traços da função ambiental da propriedade privada no direito brasileira, p. 119-136. In: Propriedade e meio ambiente: da inconciliação à convergência. MATIAS, João Luís Nogueira. WACHOWICZ, Marcos. (org.) Florianópolis: Fundação Boiteux, 2011, p. 119. 
O conceito de propriedade, portanto, desenvolve-se concomitantemente com a transição da fase do homem selvagem para a do homem sedentário, quando a civilização assenta-se em espaços físicos determinados, passando a retirar da terra seu sustento e valores. Caio Mário entendia a propriedade como fenômeno espontâneo, decorrente da necessidade de subsistência social pacífica ${ }^{5}$.

$\mathrm{Na}$ Antiguidade, a propriedade era integrada à religião ${ }^{6}$, apresentava caráter divino, vinculando-se à adoração aos deuses domésticos - pessoas da família que já tinham falecido. Basicamente, a família se fixava no solo e passava a cultuar o lugar e seus ancestrais, conferindo, desse modo, um caráter sagrado à propriedade. ${ }^{7}$

Em Roma, no período pré-clássico, entre 754 a.C e 126 a.C, reconhecia-se a propriedade quirinária ${ }^{8}$ - decorrente da constituição da cidade de Roma, típica dos patrícios, e a propriedade sobre as terras conquistadas.

Assim, a propriedade se constituiu, num primeiro momento, em direito absoluto e perpétuo ${ }^{9}$, concedendo ao proprietário o poder de dar qualquer destinação ao bem, sem sofrer qualquer interferência do Estado, situação que foi mantida na Idade Média ${ }^{10}$, época em que o direito de propriedade era considerado como condição de manutenção da divisão social.

5 PEREIRA, Caio Mário da Silva. Instituições de Direito Civil. Volume III. Rio de Janeiro: Forense. 2003.

6 Fustel de Coulanges considera que a ideia de propriedade privada na sociedade romana estava situada na própria religião, pelo fato de que cada família tinha o local de residência e de seus antecedentes como um lugar sagrado, onde os espíritos dos antecedentes protegiam sucessores ali residentes. A família romana, individualmente, possuía seus próprios deuses, representados por seus ancestrais, que protegiam tão-somente os entes de uma determinada família. O local de moradia era sagrado e nela não podiam penetrar pessoas estranhas à família. Esse caráter sagrado levou o romano a considerar a propriedade como inalienável, transmitindo-se, tão somente, para a descendência do proprietário, excluindo qualquer outra forma de alienação

7 COULANGES, Fustel de. A cidade Antiga. São Paulo: Edameris, 1966, v.1.

8 Para Costa (2003), a proteção conferida pelo Estado à propriedade quirinária era tanta que ela gozava de imunidade fiscal, posto que a cobrança tributária representaria diminuição à onipotência do pater familiae exercendo este, então, um poder político e jurisdicional sobre o seu núcleo familiar.

9 O poder ideológico do detentor da propriedade, ainda nos primórdios da civilização humana, fica evidente com o surgimento dos clãs religiosos, época em que a figura do chefe de família (depois, pater famílias para o Direito Romano) tem destaque e liderança sobre as demais pessoas fixadas em um território. Tanto o Império grego como o Império romano implicaram a eventual liderança ideológica e, posteriormente, econômica ao conceito de propriedade, trazendo os jurisconsultos romanos à tona o conceito de direito de propriedade como algo absoluto, indisponível, quase uma garantia fundamental do indivíduo.

Interessante notar que a visão da propriedade como algo absoluto passa incólume também durante o período da Idade Média, quando o direito de propriedade é mantido inclusive como condição de manutenção da divisão social, havendo uma concentração imobiliária nas mãos de poucos que detinham certo poder social sobre os demais indivíduos. GROSSI, Paolo. La propriedad y las propriedades: um Análisis Histórico. Madrid: Editorial Civitas, 1992. p. 31-32.

10 GROSSI, Paolo. La propriedad y las propriedades: um Análisis Histórico. Madrid: Editorial Civitas, 1992. p. 31-32. 
Cássia Celina Costa, no entanto, alerta que a Idade média contrariou o modelo exclusivista da propriedade romana, instituindo uma superposição de titularidades dominiais, fundamentada na hierarquia dos feudos e das pessoas, com isso, o conceito de propriedade abandona o caráter unitário para consagrar uma superposição de direitos sobre o mesmo bem, tendo cada um deles a mesma natureza, contudo, com densidades diferentes ${ }^{11}$.

Resulta, daí, os desdobramentos das faculdades entre o titular do domínio e o efetivo possuidor (usufrutuário, por exemplo), propiciando o aparecimento de outras formas coletivas ou comuns de propriedade.

No Estado Liberal, por sua vez, retomou-se a noção de propriedade individual, entretanto, com perspectiva democrática. A partir da transição da Idade Média para a Idade Moderna, os ideais iluministas que permeavam a Europa e a América, principalmente ao longo do século XVII e XVIII, trouxeram à tona duas importantes vertentes, a jusnaturalista ${ }^{12}$, que buscou positivar a propriedade como direito fundamental e individual, anterior à sociedade e ao Estado, cabendo a este respeitá-lo e a contratualista ${ }^{13}$, que defendia a propriedade como fruto da ação racional do homem.

Nesse cenário, a positivação da propriedade adquire um contorno contratual, sobretudo, na Carta Constitucional norte-americana, oriunda da Convenção de Filadélfia, de 1787, e na Declaração dos Direitos do Homem e do Cidadão, de 1789 , na França ${ }^{14}$, as quais estabeleceram a incolumidade do direito indivi-

11 COSTA, Cássia Celina Paulo Moreira da. A Constitucionalização do Direito de Propriedade Privada. Rio de Janeiro: América Jurídica, 2003.

12 Locke defende como direitos naturais do homem, inerentes à sua própria condição e independentemente do poder soberano, a Liberdade e a Propriedade. Em sua obra Segundo Tratado sobre o governo, sustenta que o Estado tem origem em um contrato realizado entre os homens, através do qual deixariam de viver em seu estado natural, passando ao Estado Social tendo em vista, principalmente, a preservação da propriedade. LOCKE, John. Carta Acerca da Tolerância; Segundo Tratado sobre Governo; Ensaio Acerca do Entendimento Humano, pág. 344.

13 Para Hobbes, a origem do estado e/ou da sociedade está em um contrato - os homens viveriam naturalmente sem poder e organização - que somente surgiria depois de um pacto firmado por eles, estabelecendo as regras de convívio social e de subordinação política. Essa é a visão do contratualismo, ou seja, a organização política da sociedade e do estado. RIBEIRO, Renato Janine. Hobbes: o medo e a esperança. In: WEFFORT, Francisco C. Os clássicos da Política. 12. ed. São Paulo: Ática, 1986. p. 53.

14 Sylvia Di Pietro defende a ideia de que a concepção romana da propriedade se restabeleceu no século XVIII, afirmando que na França, após a Revolução, a propriedade aparece, na Declaração dos Direitos do Homem e do Cidadão, como um direito inviolável e sagrado. A preocupação em assegurar a liberdade individual, a igualdade dos homens e a reação ao regime feudal levaram a uma concepção individualista exagerada de propriedade, caracterizada como direito absoluto, exclusivo e perpétuo, não sendo admitidas, inicialmente, outras restrições, senão as decorrentes das normas sobre vizinhança, que determinavam algumas obrigações ao proprietário.

O posicionamento dos juristas, no sentido de entender a propriedade, no período da Revolução Francesa, como uma reedição do conceito absolutista da idade romana, encontra contestadores que propugnam pela existência de diferenciações básicas entre o conceito de propriedade nos dois momentos históricos indicados. DI PIETRO, Maria Sylvia Zanella. Servidão administrativa. 
dual de propriedade, que permaneceu por gerações como um direito absoluto, imprescritível, inalienável ${ }^{15}$.

Em seguida, a passagem da Idade Moderna para a Contemporânea, marcada pelo processo de Revolução Industrial, evidenciou o conflito entre o modelo econômico capitalista inserto na relação capital/trabalho das fábricas, com o modelo socialista que se desenvolvia no Leste da Europa, fortalecido pelos movimentos sindical/anarquista, que exigiam uma postura positiva do Estado, no sentido de prover necessidades básicas dos cidadãos (saúde, trabalho, educação, previdência social) e, também, de restringir as liberdades da burguesia, inclusive, limitando-se a propriedade privada.

Franzoni ${ }^{16}$ ressalta que a concentração capitalista tornava cada vez mais precária a situação das pessoas que não eram proprietárias, pois a propriedade apresentava fim em si mesma, servia de capital para gerar mais capital.

Ante aos evidentes excessos no exercício do direito de propriedade e à alteração do paradigma de formulação de direitos fundamentais ocorridos depois das revoluções liberais, cai por terra a noção de que o direito de propriedade fosse absoluto, sendo dado, desde então, novo tratamento constitucional à questão ${ }^{17}$, passando o direito de propriedade a ter cunho social.

São Paulo: Revista dos Tribunais, 1978.

Nesse sentido, Adrogue afirma que a Revolução Francesa suprimiu o regime feudal da propriedade, restabeleceu a estrutura da propriedade romana em seus aspectos técnicojurídicos. Entretanto, assevera o autor que, ideologicamente, a propriedade foi entendida de forma diferente nos referidos períodos históricos, pois na concepção romana a propriedade era evidenciada pelo autoritarismo, tinha conotação militar, religiosa e política, sendo utilizada para assegurar a supremacia das famílias romanas. A propriedade na era Napoleônica foi resultado da união de pequenos e médios possuidores com a burguesia em oposição ao rei e à nobreza, com a pretensão de separar o poder político do poder econômico. ADROUGUE, Manuel. El derecho de propiedad en La actualidad. Buenos Aires: Aleledo-Perrot, 1991.

15 Explicita José Afonso da Silva: “o caráter absoluto do direito de propriedade, na concepção da Declaração Universal dos Direitos do Homem e do Cidadão de 1789 (segundo a qual seu exercício não estaria limitado senão na medida em que ficasse assegurado aos demais indivíduos o exercício de seus direitos) foi sendo superado pela evolução, desde a aplicação da teoria do abuso do direito, do sistema de limitações negativas e depois também de imposições positivas, deveres e ônus, até chegar-se à concepção de propriedade como função social, e ainda à concepção de propriedade socialista, hoje em crise”. SILVA, José Afonso da. Comentário contextual à Constituição. 3. ed. São Paulo: Malheiros, 2007. p. 117.

16 FRANZONI, Denise Paulus de Campos. Público e Privado: Divisão, Dicotomia e realidade. OLIVEIRA, Álvaro Borges de \& PASOLD, César Luiz. Teoria Jurídica das Relações Interpessoais. Florianópolis: Momento Atual, 2004.

17 Segundo Jorge Miranda: "nas constituições liberais, como se sabe, ele (o direito de propriedade) surge a par da liberdade e da segurança como componente da sua idéia de direito; ou é considerado uma liberdade tão cuidadosamente protegida como as restantes. Já em constituições de tendências sociais, ainda quando não se dissocia dos direitos fundamentais, fica condicionado por outros interesses e valores da ordem econômica e posto a serviço de uma função social. E nas constituições do tipo soviético fica reduzida aos bens que dele positivamente podem ser objecto e reduzido na sua força preceptiva perante a lei e a administração". MIRANDA, Jorge. Manual de direito Constitucional. Direitos fundamentais. Portugal: Coimbra Editora, 2000. tomo IV, v. 3, p. 523. 
Por conseguinte, no Estado social, a noção de propriedade passa a ser compreendida no contexto da coletividade, sendo submetida à função social que impõe uma série de limitações quanto ao seu exercício. A Constituição mexicana de 1917 e a de Weimar de 1919 foram as primeiras a conceder novo tratamento à propriedade, concebendo-a como direito relativizado pela dimensão do bem-estar social ${ }^{18}$.

No Brasil, na Carta Imperial de 1824 e na Carta Republicana de 1891, vigia um conceito individualista de propriedade, garantindo o "direito de propriedade em toda sua plenitude”, só excepcionado pela desapropriação. A Constituição de 1934 introduziu a garantia de que o direito de propriedade não poderia ser exercido contra o interesse social ou coletivo ${ }^{19}$.

A Constituição de 1946, a seu turno, trata da função social ao ressaltar que "o uso da propriedade será condicionado ao bem-estar social”, podendo a lei "promover a justa distribuição da propriedade, com igual oportunidade para todos”. Entretanto, apenas a partir da Constituição de 1967, que o termo Função social da Propriedade passa a fazer parte do ordenamento jurídico brasileiro como princípio da ordem econômica ${ }^{20}$.

Seguindo essa linha de evolução, finalmente, chega-se ao Estado Democrático de Direito, aquele em que o direito da propriedade passa a possuir conotação de direito fundamental, exercido de forma a compatibilizá-lo com a utilidade social.

Destarte, a Constituição da República de 1988 passou a garantir o direito de propriedade como um direito fundamental individual, visando a assegurar ao ser humano a própria liberdade e dignidade. No entanto, condiciona o seu exercício ao cumprimento da sua função social (art. $5^{\circ}$, XXIII, CR/88), indicando que a propriedade deixou de ser um direito absoluto.

Além disso, o direito de propriedade também representa um dos princípios fundamentais da ordem econômica do Brasil (art. 170, II e III, CR/88), consubstanciando uma proteção ao aproveitamento econômico do bem. Em outras palavras, a propriedade, além de atender às necessidades particulares do proprietário, deve se harmonizar aos interesses da sociedade.

18 Advém desse período o conceito de função social como algo amplo, não aplicável especificamente ao direito de propriedade. A discussão acerca dos efeitos de um instituto jurídico sobre a sociedade pode levar, de certa forma, à relativização deste em nome do bem-estar social. A idéia de autonomia do conceito função social em relação à norma que positiva o direito dá a dimensão do novo conceito que terá o instituto jurídico da propriedade a partir dessa nova visão de Estado, também voltado para a promoção do bem-estar. RENNER, Karl. The institutions of private law and their Social Functions. (Trad. Agnes Schwarzchild). Routledge \& Kegan Paul, London: 1949 . p. 75.

19 SOARES, Vivian Bacaro Nunes Soares. O Direito de Propriedade: Caracterização na Concepção de Autores Clássicos e Contemporâneos e Breves Comentários acerca da Função Social. p. 10. Disponível em: <https://www.diritto.it/pdf_archive/21748.pdf>. Acesso em 21 jan. 2019

20 SOARES, Vivian Bacaro Nunes Soares. O Direito de Propriedade: Caracterização na Concepção de Autores Clássicos e Contemporâneos e Breves Comentários acerca da Função Social. p. 10. Disponível em: <https://www.diritto.it/pdf_archive/21748.pdf>. Acesso em 21 jan. 2019. 
Como se observa, o conceito de propriedade - instituto jurídico e político, liga-se diretamente ao grau de complexidade das relações sociais e econômicas de cada época, devendo ser interpretado de maneira dinâmica, pois a ordem jurídica se conforma à nova realidade social.

Nessa perspectiva de evolução social, durante a crise do petróleo, na década de 60, objetivando inaugurar uma nova configuração de investimento capaz de impulsionar os setores da construção civil, turístico e hoteleiro, surgiu na França, o instituto da multipropriedade imobiliária, sob a denominação de multipropriéte. Em seguida, passou a ser conhecido como pluripropriéte, propriéte spatio-temporelle, copropriété saisonnière e droit de jouissance à temps partagé ${ }^{21}$.

Tal figura jurídica nasce no contexto da economia compartilhada ${ }^{22}$, tendência mundial pela qual pessoas oferecem ativos subutilizados por meio de novas práticas comerciais. Sobre a criação da multipropriedade, Mônica Paula Margarida destaca:

No mercado hoteleiro, criou-se a multipropriedade imobiliária e a inovação veio através do Timesharing e do Fractional, conceitos já consolidados nos Estados Unidos e países europeus. O diferencial entre eles está na natureza de ambos, uma vez que Fractional está relacionado ao direito real, enquanto o Timesharing trata de direito contratual.

No Fractional, a pessoa é detentora de uma fração da propriedade, ou seja, possui o título do bem e todos os direitos inerentes a este, podendo vendê-la a qualquer tempo e lucrar com a sua eventual valorização. Os multiproprietários, podem, portanto, dividir as despesas e custos do bem conforme a sua utilização e podem ainda estipular uma taxa de arrecadação periódica para cobrir os custos fixos.

Este modelo de propriedade compartilhada permite acessibilidade a empreendimentos de grande porte, sem disponibilizar um elevado volume financeiro, o contrário de aquisição da propriedade full. Desta forma, ao adquirir a propriedade, o direito de uso, ainda que regulado em sistema de rodízio com os demais proprietários é eterno.

Em sentido oposto, tem-se o Timesharing, onde adquire-se somente "unidades de tempo" que garantem direito de uso do bem por tempo pré-fixado. $\mathrm{Ou}$ seja, geralmente, trata-se de relação consumerista, pois o usuário não detém, de fato, uma fração ideal do bem, mas somente o direito de hospedagem em determinada janela temporal, conforme contrato de prestação de serviço com prazo de vigência pré-estabelecido.

Assim, no Fractional há aquisição da propriedade imobiliária, com o registro junto a matrícula do imóvel, onde o comprador torna-se dono da fração ad-

21 A droit de jouis-sance à temps partagé foi disciplinada pela Lei 86-18, de 16 de janeiro de 1986, tendo como suporte a Lei francesa de 28 de junho de 1938, cujo objetivo era disciplinar as edificações de condomínios. A rigor, tal figura jurídica se inspirou na legislação condominial, contudo, não conseguiu adaptar às suas especificidades, resultando no seu enfraquecimento. MELO, Marcelo Augusto Santana de. Multipropriedade Imobiliária. Revista de Direito Imobiliário, ano 34, v. 70. p. 19-81. jan.-jun./2011, p. 2.

$22 \mathrm{O}$ ato de compartilhar, efetivamente, se tornou mais fácil com o desenvolvimento recente da tecnologia social comunicativa, a qual permite a conexão de indivíduos absolutamente desconhecidos, gerando, dentre outros, um incentivo à colaboração. 
quirida, com todos os ônus e bônus que envolvem uma propriedade, enquanto que no Timesharing há uma prestação de serviço de longo prazo, enquadrada como relação consumerista onde não há aquisição de propriedade mas apenas cessão do direito de uso, em caráter temporário ${ }^{23}$.

A autora defende que a multipropriedade surgiu sob duas vertentes o Timesharing e o Fractional. O primeiro se relaciona com uma relação jurídica de direito obrigacional, pela qual o contratante adquire somente "unidades de tempo", que garantem direito de uso do bem por tempo pré-fixado. No Brasil, o Time-sharing está positivado nos arts. 28 e 29 do Decreto-Lei n ${ }^{\circ} 7.381 / 2010^{24}$, que regulamenta a Lei $n^{\circ} 11.771 / 2008$ (Lei do Turismo).

No âmbito da Fractional, por sua vez, há aquisição da propriedade imobiliária registrada junto a matrícula do imóvel, hipótese em que o comprador se torna proprietário da fração temporal adquirida, com todos os ônus e bônus que envolvem uma propriedade, exatamente como positivado pela Lei n ${ }^{\circ}$ 13.777/2018, sob a nomenclatura de multipropriedade.

Nos Estados Unidos, o time-sharing, despontou na Flórida, expandindo-se posteriormente pelo resto do País, em distintas modalidades: fee ownership time-sharing (direito real sobre coisa alheia) e non-fee ownership time-sharing (direito de gozo). O time-sharing, então, é administrado tanto como direito real

23 MARGARIDA, Mônica Paula. Fractional X Timesharing. Disponível em: < http://revista.turismocompartilhado.com.br/2018/06/25/fractional-x-timesharing-e-a-usufruicao-da-propriedade-por-monica-paula-margarida/>. Acesso em 28 jan. 2019.

24 Art. 28. Considera-se hospedagem por sistema de tempo compartilhado a relação em que o prestador de serviço de hotelaria cede a terceiro o direito de uso de unidades habitacionais por determinados períodos de ocupação, compreendidos dentro de intervalo de tempo ajustado contratualmente.

$\int 1^{\circ}$ Para fins do cadastramento obrigatório no Ministério do Turismo, somente prestador de serviço de hotelaria que detenha domínio ou posse de pelo menos parte de empreendimento que contenha unidades habitacionais hoteleiras poderá celebrar o contrato de hospedagem por sistema de tempo compartilhado.

$\int 2^{\circ}$ Os períodos de ocupação das unidades habitacionais poderão ser utilizados pelo próprio cessionário ou por terceiro por ele indicado, conforme disposto contratualmente.

$\int 3^{\circ}$ Os períodos de ocupação das unidades habitacionais do sistema de tempo compartilhado poderão ser representados por unidades de tempo ou de pontos.

$\mathbb{S} 4^{\circ}$ O período de utilização das unidades habitacionais poderá ser:

I - fixo, quando estipulada data específica para a sua utilização; e

II - flutuante, em que não se estipula previamente o período para utilização das unidades habitacionais dentro do intervalo de tempo ajustado contratualmente.

Art. 29. O prestador de serviço de hotelaria poderá utilizar unidades habitacionais hoteleiras de estabelecimentos definidos no art. 24, inciso II, da Lei no 11.771, de 2008, pertencentes a terceiros, para fins de cessão dentro do sistema de tempo compartilhado.

Parágrafo único. A autorização para o uso da unidade habitacional prevista no caput deverá ser formalizada em contrato com o proprietário, devendo seu prazo ser observado em eventual contrato a ser firmado entre o prestador de serviços de hotelaria e o usuário. 
como direito pessoal, permanecendo a ambiguidade no tocante à natureza jurídica da figura multiproprietária ${ }^{25}$.

Conclui-se, portanto, que a Multipropriedade em todas as suas variações contribuem para o setor Imobiliário e proporcionam maior acesso à propriedade.

\section{A NATUREZA JURÍDICA DA MULTIPROPRIEDADE}

Aplicado em experiências jurídicas estrangeiras, a Multipropriedade materializou-se por meio de modelos diferenciados, gerando efeitos inerentes a natureza jurídica de cada regime.

Diante desse contexto, apresenta-se as espécies de multipropriedade listadas por Gustavo Tepedino - multipropriedade societária; de direito real sobre coisa alheia, hoteleira e imobiliária, analisando-as sob o prisma da natureza jurídica de sua configuração.

\subsection{MULTIPROPRIEDADE SOCIETÁRIA OU ACIONÁRIA}

A sociedade multiproprietária é a modalidade aplicada na França, prevista na Lei $\mathrm{n}^{\circ}$ 86-18, de 6 de janeiro de 1986, sob a nomenclatura sociétés d'attribution d'immeuble en jouissance a temps partagé ${ }^{26}$

Segundo Tepedino, cuida-se de "multipropriedade mobiliária”, "pela qual se constitui uma sociedade, proprietária do empreendimento, da qual os adquirentes se tornam sócios, conferindo-lhes o direito de utilização periódica de certa unidade" ${ }^{27}$.

Nessa espécie, uma sociedade anônima será proprietária do bem imóvel, o qual será repartida a sua utilização, por meio da subscrição de ações específicas representativas da fração de tempo que o detentor poderá desfrutar do imóvel. Assim, o direito do sócio multiproprietário vem incorporado a uma ação ou título representativo de sua condição de acionista.

Tal hipótese se afasta da noção tradicional de propriedade, constituindo-se a multipropriedade societária de natureza jurídica de direito pessoal e societário, no qual o acionista dispõe do direito de usar o imóvel de propriedade da socieda-

25 THE FLÓRIDA SENATE. 2015 Florida Statutes, Title XL Real and Personal Property, Chapter 721.05. Disponível em: <https:/www.flsenate.gov/Laws/Statutes/2015/721.05>. Acesso em 30 jan. 2019.

26 Esclareça-se que as primeiras grandes operações imobiliárias surgiram, na França, no século $\mathrm{XX}$, com viés na constituição de condomínios e edifícios, sem que houvesse qualquer legislação específica. Os negócios imobiliários eram regidos por dois sistemas de construção: o método Grénoble e o método de Paris. O primeiro se relaciona à compra de um terreno, em que seus quinhões eram divididos entre os condôminos e procedia-se a edificação coletiva, sendo regulamentado como condomínio previsto no Código de Napoleão. O segundo instituía uma sociedade para o desenvolvimento de uma edificação, e depois de finalizada a construção havia a transferência do patrimônio social para a co-titularidade dos condôminos. Tais sistemas não obtiveram êxito. TEPEDINO, Gustavo. Multipropriedade Imobiliária. São Paulo: Saraiva, 1993, p. 24.

27 TEPEDINO. Gustavo. Multipropriedade imobiliária. São Paulo: Saraiva, 1993, p. 1 
de, durante o tempo determinado por suas ações representativas, a cada ano, de forma cíclica. Ou seja, o acionista adquire o direito de utilização do patrimônio social da empresa - o imóvel, sem que tenha havido transmissão do domínio, que continua pertencendo à sociedade.

Como não há transferência de propriedade, inexiste direito real, mas sim direito obrigacional e mobiliário de gozo turnário sobre o imóvel da sociedade, decorrente de títulos ou ações representativas - bens móveis, a teor do Código Civil Brasileiro.

Observa-se, pois, que além de inexistir direito real na espécie societária, a natureza jurídica obrigacional resulta na dependência do multiproprietário à condução da sociedade e a seu estatuto, tornando o acionista vulnerável à eventual possibilidade de dissolução, fusão, cisão ou incorporação da sociedade anônima, ficando evidente que são muitos os fatores que poderão influenciar o exercício do gozo da propriedade, o que acaba dificultando a aplicação do regime.

$\mathrm{Na}$ Itália, a primeira modalidade de multipropriedade implementada também teve caráter societário e mobiliário. No entanto, o insucesso dessa espécie, na maior parte dos países, cedeu lugar à busca de segurança jurídica inerente à multipropriedade imobiliária.

\subsection{MULTIPROPRIEDADE REAL SOBRE COISA ALHEIA}

Em Portugal, a multipropriedade é classificada em direito real sobre coisa alheia, pelo qual o multiproprietário é tido como detentor de direito real limitado, incidente sobre propriedade que se mantém no patrimônio jurídico do empreendedor.

Disciplinado por meio do Decreto-Lei n ${ }^{\circ} 275 / 93$, alterado pelos Decretos-Lei n ${ }^{\circ} 180 / 99,37 / 2011$, a multipropriedade portuguesa permite, nos termos do art. $1^{\circ}$ do Decreto-Lei $\mathrm{n}^{\circ} 275 / 93$, que "unidades de alojamento integradas em hotéis-apartamentos, aldeamentos turísticos e apartamentos turísticos podem constituir-se direitos reais de habitação periódica limitados a um período certo de tempo de cada ano" 28 .

Trata-se do direito de usar uma unidade de alojamento integrada num empreendimento turístico, para fins habitacionais, por um ou mais períodos certos, em cada ano, mediante pagamento de prestação periódica ao proprietário do empreendimento ou a quem o administre ${ }^{29}$.

O direito real de habitação periódica é perpétuo, constituído por escritura pública $\left(\operatorname{art.~} 6^{\circ}\right.$ ), registrado no respectivo Registro de Imóveis (art. $8^{\circ}$ ), podendo ser fixado um limite de duração não inferior a um ano.

28 MESQUITA, Henrique. Uma nova figura real: o direito de habitação periódica, in: Revista de Direito e Economia. Universidade de Coimbra, 1982. p. 1: 39-69.

29 FERNANDES, Edésio. A nova ordem jurídico-urbanística do Brasil. Minas Gerais: Del Rey, 2006. p. 33. 
Revestido de natureza jurídica de direito real limitado sobre coisa alheia, deve ser criado sob o regime de condomínio especial edilício, recaindo sobre o proprietário o dever de administrar e conservar as unidades autônomas, sendo possível ratear as despesas de conservação, por meio de prestação periódica, desde que, previamente definido no título constitutivo ${ }^{30}$.

Por fim, vale ressaltar que o titular do direito de habitação periódica poderá onerar, alienar ou ceder o uso do imóvel mediante comodato ou locação.

\subsection{MULTIPROPRIEDADE IMOBILIÁRIA OU REAL}

A multipropriedade imobiliária ou real, adotada em vários países ${ }^{31}$, constitui-se na técnica de aproveitamento de móveis e imóveis, por frações de tempo, sob o regime de condomínio, assegurando a cada coproprietário o direito de uso e gozo exclusivo e perpétuo, durante certo período anual.

Destacam-se, na doutrina, duas espécies: a primeira consiste em outorgar um direito real limitado a título de habitação, usufruto ou a criação própria de um instituto que permita o compartilhamento da propriedade. A segunda, a seu turno, relaciona-se com a possibilidade de outorgar direito real de propriedade, condicionando à utilização à fração de tempo prevista na instituição do respectivo condomínio ${ }^{32}$, exatamente como disciplinado, no Brasil, pela Lei Lei $\mathrm{n}^{\mathrm{o}} 13.777 / 2018$.

A multipropriedade real ou imobiliária apresenta natureza jurídica de direito real, sendo a aquisição do imóvel realizada por meio de escritura pública registrada em Cartório de Imóveis, correspondendo à quota-parte ideal da unidade autônima, ao período de tempo anual de utilização do bem.

Pelo exposto, a espécie confere maior segurança ao adquirente, inclusive, permitindo a transmissão a herdeiros e legatários, nos termos do Direito Sucessório Brasileiro.

\subsection{MULTIPROPRIEDADE HOTELEIRA}

A modalidade conhecida como hoteleira não se constitui, por si só, uma espécie de multipropriedade, sendo, normalmente, associada a outra multipropriedade já estudada.

30 MESQUITA, Henrique. Uma nova figura real: o direito de habitação periódica, in: Revista de Direito e Economia. Universidade de Coimbra, 1982. p. 1: 39-69.

31 Com essa modalidade, diversos mercados imobiliários conseguiram superar a crise recessiva em que se encontravam (como ocorreu na Espanha, em Portugal e na Itália, quando do surgimento das respectivas leis nacionais e da diretiva europeia). TEPEDINO, Gustavo. A multipropriedade e a retomada do mercado imobiliário Disponível em <https://www.conjur.com. br/2019-jan-30/tepedino-multipropriedade-retomada-mercado-imobiliario>. Acesso em 31 jan. 2019.

32 MELO, Marcelo Augusto Santana de. Multipropriedade Imobiliária. Disponível em: < http:// www.anoreg.org.br/index.php?option=com_content \&view=article\&id=27589: multipropried ade-imobiliaria-por-marcelo-augusto-santana-de-melo\&catid=32\&Itemid=181>. Acesso em 30 jan. 2019. 
Segundo Gustavo Tepedino, "trata-se da conjugação do sistema multiproprietário, concebido ora mediante a modalidade imobiliária, ora através da fórmula societária, com os serviços de hotelaria desenvolvidos por empresa do ramo hoteleiro" ${ }^{33}$.

Normalmente associada à multipropriedade imobiliária, na prática, a pessoa adquire a propriedade de fração temporal do imóvel compartilhado, agregando a transferência da gestão dos serviços à empresa hoteleira, de modo a ocorrer, no mesmo empreendimento o duplo regime.

Tepedino enfatiza a vantagem da transferência da gestão dos serviços à empresas especializadas:

a entrega da gestão multiproprietária a redes de hotelaria, em geral empresas multinacionais, estimula a prática de intercâmbio entre multiproprietários, visando à permuta anual das respectivas frações de que são titulares, em lugares e países diversos, formando-se um chamado "banco de trocas", altamente diversificado e interessante para os que gostam de viajar. Dessa forma, um multiproprietário titular de uma quinzena anual em Cannes, por exemplo, troca a utilização do seu apartamento, em certo ano, com titular de direito em imóvel situado em Búzios ou nas distantes Ilhas Mauricius ${ }^{34}$

A multipropriedade hoteleira, destarte, constitui-se de natureza jurídica obrigacional, objetivando garantir aos multiproprietários, o melhor aproveitamento da sua fração temporal, tornando atrativo o empreendimento.

Os titulares de tal espécie, contudo, responsabilizavam-se em comunicar à rede hoteleira, anualmente, o período de fruição do imóvel, ou ainda se optam em aproveitá-lo em outra época do ano, intento este que deverá ser atendido com preferência sobre terceiros, desde que haja disponibilidade de reserva.

Tal esquema negocial apresenta-se vantajoso ao ramo imobiliário, pois, num só tempo, estimula à expansão do setor hoteleiro, eliminando os períodos de escassa ocupação, já que os multiproprietários acabavam por preencher o hotel por todo o ano, além de elevar a qualidade dos serviços prestados, uma vez que cabia ao hotel a administração do imóvel

\subsection{A NATUREZA JURÍDICA DA MULTIPROPRIEDADE IMOBILI- ÁRIA ADOTADA NO BRASIL}

Como a autonomia privada se antecipou ao legislador, no Brasil, a controvérsia sobre a natureza jurídica da multipropriedade foi dissipada pelo STJ, no julgamento do REsp 1.546.165/SP, antes do advento da Lei n ${ }^{\circ} 13.777 / 2018$.

De um lado, adeptos do seu enquadramento na classe direito pessoal ou obrigacional defendiam a existência de verdadeiro direito real atípico, espécie que não poderia existir, por violar o princípio da taxatividade dos direitos reais,

33 TEPEDINO. Gustavo. Multipropriedade imobiliária. São Paulo: Saraiva, 1993, p. 18-19.

34 TEPEDINO. Gustavo. Multipropriedade imobiliária. São Paulo: Saraiva, 1993, p. 19. 
previsto no art. 1225 do Código Civil. Assim, ante a impossibilidade de criação de um direito real por convenção privada, conferia-se ao instituto da multipropriedade natureza jurídica de caráter pessoal ${ }^{35}$.

Lado outro, defendia-se o entendimento de que os direitos reais decorrem dos poderes exercidos pelo multiproprietário sobre o imóvel - usar, gozar, dispo e reivindicar, em virtude de direito próprio, perpétuo, no entanto, limitado ao período de tempo anual preestabelecido.

Pois bem.

Seguindo essa linha de raciocínio, em 2016, o STJ reformou a decisão do Tribunal de Justiça de São Paulo (TJSP), que havia admitido a penhora de uma casa no condomínio Praia das Caravelas, no Município de Búzios, Rio de Janeiro $^{36}$. O imóvel, registrado em nome de uma incorporadora - executada em ação judicial -, é dividido em 52 quotas de propriedade no sistema de multipropriedade, as quais dão a seus titulares o direito de utilização em semanas específicas ${ }^{37}$.

No julgamento do Recurso Especial 1.546.165/SP38, a $3^{\mathrm{a}}$ Turma do Superior Tribunal de Justiça decidiu, por maioria, que a multipropriedade tem natureza de direito real e, no caso de penhora do imóvel objeto de compartilhamento, o coproprietário pode se valer de Embargos de Terceiro para proteger sua quota-parte.

O Relator, Ministro Ricardo Villas Bôas Cueva, em seu voto, defendeu a natureza de direito pessoal para multipropriedade, argumentando que:

trata-se de situação jurídica complexa e atípica que envolve relações obrigacionais específicas interligadas por diversas fontes de interesses - os multiproprietários entre si, e entre estes e a administração do empreendimento - em colaboração recíproca para a satisfação na utilização do bem ${ }^{39}$.

35 BRASIL. Superior Tribunal de Justiça. RE n. 1.546.165-SP/2014 - Voto Vencido do Ministro Ricardo Villas Bôas Cueva. Disponível em: <http://www.portaldori.com.br/wp-content/ uploads/2016/09/AC\%C3\%93RD\%C3\%83O-NOTICIA-SEXTA-23.09.pdf>. Acesso em 29 jan. 2019.

36 Detalhando-se o caso: foi realizada a penhora da totalidade do imóvel e uma das multiproprietárias, titular de 2/52 do bem, interpôs Embargos de Terceiro para que fosse afastada a constrição judicial de sua fração ideal temporal. O Tribunal de Justiça de São Paulo negou o pedido, sob o fundamento de que a cessão de direitos referente aos $2 / 52$ da casa não corresponderia a direito real de propriedade, mas a direito obrigacional, "uma vez que o imóvel foi registrado em nome da devedora, que figurou como centralizadora do contrato e organizadora da utilização periódica do bem".

37 BRASIL. Superior Tribunal de Justiça. Terceira Turma reconhece multipropriedade como direito real e afasta penhora. Disponível em: <https://stj.jusbrasil.com.br/noticias/386289514/ terceira-turma-reconhece-multipropriedade-como-direito-real-e-afasta-penhora>. Acesso em 30 jan. 2019.

38 BRASIL. Superior Tribunal de Justiça. RE n. 1.546.165-SP/2014 - Voto Vencedor do Ministro João Otávio de Noronha. Disponível em: <http://www.portaldori.com.br/wp-content/uploads/2016/09/AC\%C3\%93RD\%C3\%83O-NOTICIA-SEXTA-23.09.pdf>. Acesso em 29 jan. 2019.

39 BRASIL. Superior Tribunal de Justiça. RE n. 1.546.165-SP/2014 - Voto Vencido do Ministro Ricardo Villas Bôas Cueva. Disponível em: <http:/www.portaldori.com.br/wp-content/ uploads/2016/09/AC\%C3\%93RD\%C3\%83O-NOTICIA-SEXTA-23.09.pdf>. Acesso em 29 
Concluiu o Relator que a multipropriedade é direito pessoal, uma vez que se trata de contrato regulando condutas de propriedade pertencente a terceiros.

No entanto, o Ministro João Otávio de Noronha apresentou entendimento divergente e foi acompanhado pela maioria da turma. Fundamentou que aquele "que detém as faculdades de uso, gozo e disposição sobre fração ideal do bem, ainda que objeto de compartilhamento pelos multiproprietários de espaço e turnos fixos de tempo" - é possuidor de um direito real e prossegue:

A multipropriedade imobiliária, nada obstante ter feição obrigacional aferida por muitos, detém forte liame com o instituto da propriedade, se não for a sua própria expressão, como já vem proclamando a doutrina contemporânea, inclusive num contexto de não se reprimir a autonomia da vontade nem a liberdade contratual diante da preponderância da tipicidade dos direitos reais e do sistema de numerus clausus $^{40}$.

Por conseguinte, o colegiado reconheceu que os atributos dos direitos reais se harmoniza ao vínculo jurídico de aproveitamento econômico compartilhado do imóvel, objeto de controvérsia, julgando procedentes os Embargos de Terceiro e declarando insubsistente a penhora sobre a totalidade do imóvel.

Nesse cenário, conclui-se que a multipropriedade é uma espécie de propriedade, instituída sob a forma de "condomínio especial" 41 , enquadrando-se no rol dos direitos reais previsto no art. 1.225, I do Código Civil Brasileiro, devendo ser registrada na matrícula do imóvel, a peculiaridade de fracionamento do tempo de utilização do imóvel por cada um dos coproprietários.

Demonstrada a natureza jurídica de Direito Real da multipropriedade, passa-se a abordar as peculiaridades e de sua instituição.

\section{PECULIARIDADES E EFEITOS DA MULTIPROPRIEDADE}

A instituição da multipropriedade pode se dar por ato inter vivos- contrato de compra e venda - ou mortis causa - testamento, registrado no competente

jan. 2019.

40 BRASIL. Superior Tribunal de Justiça. RE n. 1.546.165-SP/2014 - Voto Vencedor do Ministro João Otávio de Noronha. Disponível em: <http://www.portaldori.com.br/wp-content/uploads/2016/09/AC\%C3\%93RD\%C3\%83O-NOTICIA-SEXTA-23.09.pdf>. Acesso em 29 jan. 2019.

$41 \mathrm{O}$ art. 1358-O da Lei $\mathrm{n}^{\circ}$ 13.777/2018 regulou a multipropriedade como unidade autônoma, delimitada no tempo e no espaço, inserida no regime de condomínio especial. Justificando a utilização do condomínio especial, argumenta-se que, no condomínio civil, "cada condômino pode usar da coisa conforme sua destinação, sobre ela exercer todos os direitos compatíveis com a indivisão, reivindicá-la de terceiro, defender a sua posse e alhear a respectiva parte ideal, ou gravá-la.” (art. 1.314 do Código Civil). Como não existe regra para a quantificação ou aferição da parte ideal de cada condômino, inclusive, sendo habitual, nas práticas notarial e registrária, a utilização de fração ou porcentagem para expressar a quota ideal de cada coproprietário, não há proibição, no ordenamento jurídico brasileiro, para representar a quota-parte de um condomínio em frações de tempo, como, por exemplo, a primeira quinzena do mês de janeiro ou, ainda, a terceira semana do mês de julho. Silva Filho já defendia a utilização da multipropriedade no Brasil, aplicando-se analogicamente a Lei 4591/64. SILVA FILHO, Elvino. Questões de Condomínio no Registro de Imóveis. São Paulo: Editora Malheiros, 1999, p. 139. 
Cartório de Registro de Imóveis ${ }^{42}$, devendo constar do ato a especificação dos períodos correspondentes a cada fração de tempo, nos termos dos arts. 1.358-F a 1.358-H, do CC.

O instrumento de instituição ou a convenção de condomínio em multipropriedade deverá observar, no que couber, as regras do condomínio edilício, regulamentando, especificamente, os poderes e deveres dos multiproprietários; o número máximo de pessoas que podem ocupar simultaneamente o imóvel; as regras de acesso do administrador condominial ao imóvel; a criação de fundo de reserva para reposição e manutenção do imóvel; o regime aplicável em caso de perda ou destruição; bem como regular as multas aplicáveis aos multiproprietários em caso de descumprimento de seus deveres ${ }^{43}$.

Vale dizer que o reconhecimento legal da autonomia de cada unidade ${ }^{44}$, individualizada no espaço e no tempo, com sua respectiva matrícula no registro de imóvel, inserida em regime de condomínio edilício, trouxe a segurança jurídica esperada pelo setor imobiliário.

Uma vez registrada a aquisição de fração temporal de um bem imóvel em multipropriedade, o titular adquire o direito real de propriedade do respectivo bem, que será exercido de maneira temporal, renovado anualmente, de modo cíclico e com caráter perpétuo.

42 Segundo Carlos Eduardo Elias de Oliveira: “do ponto de vista registral, haverá uma matrícula-mãe, na qual será registrada a instituição do condomínio multiproprietário com a criação de novas matrículas-filhas para as unidades periódicas. É semelhante ao que acontece com o condomínio edilício: a matrícula-mãe recebe o registro da instituição do condomínio edilício e, assim, gera matrículas autônomas para cada unidade autônoma” OLIVEIRA, Carlos Eduardo Elias de. Considerações sobre a recente Lei da Multipropriedade ou da Time Sharing (Lei $n^{\text {o } 13.777 / 2018) ~ . ~ D i s p o n i ́ v e l ~ e m ~<~ h t t p s: / / i n f o g r a p h y a . c o m / f i l e s / l e i-m u l t i p r o p r i e d a d e-I R I B-~}$ -artigo.pdf>. Acesso em 31 jan. 2019.

43 Art. 1.358-G. BRASIL. Lei n ${ }^{\circ}$ 13.777, de 20 de dezembro de 2018. Altera as Leis n⿳⺈ 10.406, de 10 de janeiro de 2002 (Código Civil), e 6.015, de 31 de dezembro de 1973 (Lei dos Registros Públicos), para dispor sobre o regime jurídico da multipropriedade e seu registro. $\mathrm{Pu}$ blicada DJE de 21/12/2018. Disponível em: <http://www.planalto.gov.br/ccivil_03/_Ato20152018/2018/Lei/L13777.htm>. Acesso em 23 jan. 2019.

44 Tepedino alerta que por se tratar de unidade autônoma, o IPTU há de ser individualizado e cobrado de cada multiproprietário, assim como as despesas de luz, gás e água próprias da respectiva unidade, sendo repartidas por cada multiproprietário as taxas condominiais que, como obrigações propter rem, oneram o patrimônio pessoal de cada titular. Essa questão se torna relevante na medida em que o presidente da República vetou dispositivos (parágrafos $3^{\circ}, 4^{\circ}$ e $5^{\circ}$ do artigo 1.358-J do Código Civil) em cuja dicção se lia: parágrafo $3^{\circ}$ : “Os multiproprietários responderão, na proporção de sua fração de tempo, pelo pagamento dos tributos, contribuições condominiais e outros encargos que incidam sobre o imóvel”; e parágrafo $4^{\circ}$ : "Cada multiproprietário de uma fração de tempo responde individualmente pelo custeio das obrigações, não havendo solidariedade entre os diversos multiproprietários”. Tal veto, contudo, não altera a autonomia das matrículas, devendo ser afastada, portanto, qualquer interpretação que pretendesse atribuir ao conjunto dos multiproprietários de um mesmo apartamento a responsabilidade solidária das referidas despesas individuais. TEPEDINO, Gustavo. A multipropriedade e a retomada do mercado imobiliário. Disponível em <https://www.conjur.com.br/2019-jan-30/ tepedino-multipropriedade-retomada-mercado-imobiliario>. Acesso em 31 jan. 2019. 
A periodicidade, portanto, se mostra o traço essencial do regime multiproprietário. Nesse aspecto, nota-se que o aproveitamento econômico do imóvel em multipropriedade é latente, sobretudo, se considerarmos o tempo mínimo da unidade periódica de 7 dias, à luz do art. 1.358-E do CC.

Tal comando permite que um único imóvel seja parcelado em até 52 unidades temporais periódicas, significando-se um tempo de ócio do bem muito reduzido em relação à propriedade tradicional. Conforme observa Afonso Rezende:

A vantagem é puramente econômica, permitindo ao adquirente usufruir de um imóvel para seu descanso de cada ano, sem suportar gastos astronômicos, bem como isentar-se do possível 'sofrimento' e mesmo desagrado das reservas de hotéis ou mesmo possibilidade de nada encontrar para o merecido repouso, enfim, com dificuldades para um alojamento cômodo e saudável. A outra vantagem do sistema é que este tipo de co-propriedade também está localizado em cidades praianas, montanhas, estâncias hidrominerais ou termais, vindo, assim, cumprir parcialmente o preceito constitucional quanto à função social da propriedade, pois se utiliza de maneira completa de um bem, satisfazendo o interesse de uma multiplicidade de sujeitos" ${ }^{45}$.

No tocante ao elemento tempo, o art. 1.358-E do CC detalha que cada fração adquirida é indivisível, sendo de, no mínimo, 7 (sete) dias, seguidos ou intercalados, podendo ser fixo e determinado, no mesmo período de cada ano; ou flutuante, caso em que a determinação do período será realizada de forma periódica, mediante procedimento objetivo que respeite, em relação a todos os multiproprietários, o princípio da isonomia ${ }^{46}$.

O sistema misto, que combina o fixo e o flutuante, também será aceito, contudo, todos os multiproprietários terão direito a uma mesma quantidade mínima de dias seguidos durante o ano, podendo haver a aquisição de frações maiores que a mínima, com o correspondente direito ao uso por períodos também maiores ${ }^{47}$.

Quanto ao objeto da multipropriedade, o legislador brasileiro restringiu a incidência do instituto ao bem imóvel - urbano ou rural, dispondo no art. 1.358-D, do CC, o caráter indivisível do bem compartilhado, que não se sujeita à ação de divisão ou de extinção de condomínio. Ademais, incluem-se no regime

45 REZENDE, Afonso Celso F. Multipropriedade Imobiliária. Disponível em: http://www.escritorioonline.com/webnews/noticia.php?id_noticia=1308\&, acessado em 12 de jan. 2019.

46 BRASIL. Lei $\mathrm{n}^{\circ} 13.777$, de 20 de dezembro de 2018. Altera as Leis $\mathrm{n}^{\mathrm{o}} \mathrm{10.406}$, de 10 de janeiro de 2002 (Código Civil), e 6.015, de 31 de dezembro de 1973 (Lei dos Registros Públicos), para dispor sobre o regime jurídico da multipropriedade e seu registro. Publicada DJE de 21/12/2018. Disponível em: < http://www.planalto.gov.br/ccivil_03/_Ato2015-2018/2018/Lei/ L13777.htm>. Acesso em 31 jan. 2019.

47 BRASIL. Lei $\mathrm{n}^{\circ} 13.777$, de 20 de dezembro de 2018. Altera as Leis $\mathrm{n}^{\mathrm{os}} 10.406$, de 10 de janeiro de 2002 (Código Civil), e 6.015, de 31 de dezembro de 1973 (Lei dos Registros Públicos), para dispor sobre o regime jurídico da multipropriedade e seu registro. Publicada DJE de 21/12/2018. Disponível em: < http://www.planalto.gov.br/ccivil_03/_Ato2015-2018/2018/Lei/ L13777.htm>. Acesso em 31 jan. 2019. 
de aproveitamento temporal, as instalações, os equipamentos e o mobiliário destinados a seu uso e gozo.

Vale lembrar, ainda, que mesmo um condomínio edilício poderá adotar o regime de multipropriedade em parte ou na totalidade de suas unidades autônomas, mediante previsão no instrumento de instituição ou deliberação da maioria absoluta dos condôminos, respeitando os comandos dos arts. 1.358-O a 1.358-U do CC.

O legislador também se ocupou em listar os direitos e obrigações dos multiproprietários, garantindo a cada um dos condôminos em multipropriedade, basicamente, o direito de usar e gozar do imóvel, incluindo-se aí sua cessão ou locação no período de tempo correspondente à sua própria fração de tempo. Assegurou, ainda, a cada condômino o direito de votar e de participar das assembleias gerais do condomínio em multipropriedade, sendo o voto proporcional à quota de fração de tempo de cada condômino (art. 1.358-I do CC).

No tocante às obrigações do multiproprietário, além daquelas previstas no instrumento de instituição e na convenção de condomínio (Art. 1.358-J do CC), fica a seu cargo pagar a contribuição condominial, ainda que renuncie ao uso e gozo, total ou parcial, do imóvel, das áreas comuns ou das respectivas instalações, equipamentos e mobiliário; responder por danos causados ao imóvel, às instalações, aos equipamentos e ao mobiliário por si; comunicar imediatamente ao administrador os defeitos, avarias e vícios no imóvel; não modificar, alterar ou substituir o mobiliário do imóvel; conservar, manter e utilizar o imóvel as instalações, equipamentos e mobiliário, conforme seu destino e natureza; desocupar o imóvel, impreterivelmente, até o dia e hora fixados no instrumento de instituição ou na convenção de condomínio em multipropriedade, sob pena de multa diária; permitir a realização de obras ou reparos urgentes.

Acrescenta-se, ainda, que a teor dos arts. 1.358-M e 1.358-N do CC, a administração do imóvel e de suas instalações, equipamentos e mobiliário, objeto da multipropriedade, será de responsabilidade da pessoa indicada no instrumento de instituição ou na convenção de condomínio em multipropriedade, ou, na falta de indicação, de pessoa escolhida em assembleia geral dos condôminos.

Ao administrador, além das tarefas elencadas no próprio instrumento de instituição da multipropriedade, caberá: coordenar a utilização do imóvel; definir, nos sistemas de fração temporal variável, o período de uso de cada um dos multiproprietários; manter e conservar o imóvel; trocar ou substituir equipamentos ou mobiliário; elaborar orçamento anual; e cobrar as quotas de cada um dos coproprietários, pagando as despesas comuns ${ }^{48}$.

48 BRASIL. Lei $\mathrm{n}^{\mathrm{o}}$ 13.777, de 20 de dezembro de 2018. Altera as Leis $\mathrm{n}^{\mathrm{os}} \mathbf{1 0 . 4 0 6}$, de 10 de janeiro de 2002 (Código Civil), e 6.015, de 31 de dezembro de 1973 (Lei dos Registros Públicos), para dispor sobre o regime jurídico da multipropriedade e seu registro. Publicada DJE de 21/12/2018. Disponível em: < http://www.planalto.gov.br/ccivil_03/_Ato2015-2018/2018/Lei/ 
Por fim, esclareça-se que a despeito das peculiaridades da multipropriedade, aplicam-se-lhe, no que couberem, as regras do condomínio edilício, a Lei 4.591/64 e do Código de Defesa do Consumidor. Este último, se houver relação de consumo envolvendo, de um lado, os multiproprietários e, de outro lado, o administrador do condomínio multiproprietário, a sociedade operadora do regime de pool (art. 1.358-S, II, do CC) ou a empresa operadora do regime de intercâmbio (art. 1.358-P, VI, do CC).

Feitas as considerações gerais, analisa-se as incidências específicas de direito de preferência, efeitos do inadimplemento do multiproprietário e possibilidade de gravames na unidade periódica

\subsection{O DIREITO DE PREFERÊNCIA NA MULTIPROPRIEDADE}

Dispõe o art. 504 do Código Civil Brasileiro ${ }^{49}$, que se um dos condôminos quiser dispor de sua cota parte, deverá, obrigatoriamente, oferecê-la a outro consorte, sob pena de nulidade do ato, nos termos da lei.

Ante tal comando, há doutrinadores defendendo a submissão da multipropriedade, constituída sob a forma de condomínio, ao direito de preferência ${ }^{50}$.

No entanto, não se concorda com tal posicionamento.

Tendo o legislador regulamentado a propriedade em unidades autônomas, a rigor, o direito de preferência previsto no art. 504 do Código Civil Brasileiro não se aplica na venda de fração temporal de imóvel entre multiproprietários, ou seja, é válida a alienação da quota-parte do coproprietário, sem o oferecimento do direito de preferência aos detentores de fração maior do imóvel.

A propósito, este já era o posicionamento adotado pela Terceira Turma do STJ, no julgamento do REsp 1.526.125, que tinha como controvérsia o direito de preferência na venda de fração ideal de imóvel indivisível em condomínio geral.

Nas palavras do Ministro Paulo de Tarso Sanseverino:

Não há direito potestativo de preferência na hipótese em que um dos condôminos aliena sua fração ideal para outro condômino, já que não se fez ingressar na copropriedade pessoa estranha ao grupo condominial, razão pela qual fora erigida a preempção ou preferência

$[\ldots]$

A conclusão que há de prevalecer, assim, é: em não havendo extinção do condomínio, é dado ao condômino escolher a qual outro condômino vender

L13777.htm>. Acesso em 31 jan. 2019.

49 BRASIL. Lei n ${ }^{\circ}$ 10.406, de 10 de janeiro de 2002. Institui o Código Civil. Brasília. Publicado Diário Oficial da União em 11.1.2002.

50 Ana Luiza Carreira; João Paulo dos Anjos Lima; Recielly Bruna Aquino Ribeiro defendem este posicionamento. CARREIRA, Ana Luiza; LIMA, João Paulo dos Anjos; RIBEIRO, Recielly Bruna Aquino Ribeiro. Multipropriedade Imobiliária. Disponível em < https://jplima3.jusbrasil.com.br/artigos/374405475/multipropriedade-imobiliaria>. Acesso em 31 jan 2019. 
a sua fração ideal, sem que isso dê azo ao exercício do direito potestativo de preferência $^{51}$.

Não bastasse o entendimento adotado pelo STJ, sepultando qualquer questionamento no ponto, o art. 1.358-L do CC previu, expressamente, que "a transferência do direito de multipropriedade e a sua produção de efeitos perante terceiros dar-se-ão na forma da lei civil e não dependerão da anuência ou cientificação dos demais multiproprietários", frisando no seu $\mathbb{S} 1^{\circ}$ que:

não haverá direito de preferência na alienação de fração de tempo, salvo se estabelecido no instrumento de instituição ou na convenção do condomínio em multipropriedade em favor dos demais multiproprietários ou do instituidor do condomínio em multipropriedade ${ }^{52}$.

Tepedino, nesse aspecto, alerta:

A rigor, por se tratar de unidade autônoma, o multiproprietário pode, como em qualquer condomínio edilício, dispor como bem entender de seu direito real de propriedade, de modo gratuito ou oneroso, desde que mantenha íntegro o liame visceral entre a propriedade individual (que lhe franqueia a utilização, com exclusividade, da fração semanal que lhe diz respeito) e a fração ideal a ela correspondente sobre as áreas comuns ${ }^{53}$.

Dessa forma, o legislador, acertadamente, explicitou que os multiproprietários não terão direito de preferência quando da alienação de qualquer outra fração de tempo do mesmo imóvel, não sendo necessária a comunicação ou concordância dos demais.

Destarte, fica ressalvada a possibilidade de se prever a preempção, em favor do instituidor do condomínio ou entre os diversos multiproprietários, no título constitutivo ou na convenção de condomínio, privilegiando o livre exercício da autonomia privada das partes.

\subsection{EFEITOS DO INADIMPLEMENTO DO MULTIPROPRIETÁRIO}

A rigor, cada multiproprietário responde individualmente pelo custeio das obrigações de sua fração temporal, não havendo solidariedade entre os diversos multiproprietários.

É o caso do IPTU, obrigação propter rem que recai sobre a fração periódica do devedor, não sendo possível responsabilizar os demais multiproprietários

51 BRASIL. Superior Tribunal de Justiça. REsp 1526125. Disponível em: <https://stj.jusbrasil. com.br/jurisprudencia/574626006/recurso-especial-resp-1526125-sp-2015-0074967-9/inteiro-teor-574626016? ref=juris-tabs>. Acesso em 31 jan. 2019.

52 BRASIL. Superior Tribunal de Justiça. REsp 1.526.125. Disponível em: <https://stj.jusbrasil. com.br/jurisprudencia/574626006/recurso-especial-resp-1526125-sp-2015-0074967-9/inteiro-teor-574626016? ref=juris-tabs>. Acesso em 31 jan. 2019.

53 TEPEDINO, Gustavo. A multipropriedade e a retomada do mercado imobiliário Disponível em <https:/www.conjur.com.br/2019-jan-30/tepedino-multipropriedade-retomada-mercado-imobiliario>. Acesso em 31 jan. 2019. 
por uma dívida própria. Até porque, no caso de inadimplemento, o Fisco poderá executar a unidade periódica do devedor para quitação da dívida tributária, sem alcançar ou prejudicar os demais multiproprietários.

Tepedino complementa:

por se tratar de unidade autônoma, o IPTU há de ser individualizado e cobrado de cada multiproprietário, assim como as despesas de luz, gás e água próprias da respectiva unidade, sendo repartidas por cada multiproprietário as taxas condominiais que, como obrigações propter rem, oneram o patrimônio pessoal de cada titular. Essa questão se torna relevante na medida em que o presidente da República vetou dispositivos (parágrafos $3^{\circ}, 4^{\circ}$ e $5^{\circ}$ do artigo 1.358-J do Código Civil) em cuja dicção se lia: parágrafo $3^{\circ}$ : “Os multiproprietários responderão, na proporção de sua fração de tempo, pelo pagamento dos tributos, contribuições condominiais e outros encargos que incidam sobre o imóvel"; e parágrafo $4^{\circ}$ : "Cada multiproprietário de uma fração de tempo responde individualmente pelo custeio das obrigações, não havendo solidariedade entre os diversos multiproprietários”. Tal veto, contudo, não altera a autonomia das matrículas, devendo ser afastada, portanto, qualquer interpretação que pretendesse atribuir ao conjunto dos multiproprietários de um mesmo apartamento a responsabilidade solidária das referidas despesas individuais ${ }^{54}$

Assim, sendo a multipropriedade vinculada à unidade autônoma, não há como atribuir ao conjunto dos multiproprietários de um mesmo apartamento, a responsabilidade solidária das referidas despesas individuais.

Por outro lado, cabe aos coproprietários ratear as despesas comuns, proporcionalmente, a sua fração temporal. Nessa hipótese, em caso de inadimplemento, por parte do multiproprietário, da obrigação de custeio das despesas ordinárias ou extraordinárias, o art. 1.358-S do CC autoriza a adjudicação ao condomínio edilício da fração de tempo correspondente, na forma prevista no CPC.

Ou seja, na hipótese de o imóvel objeto da multipropriedade ser parte integrante de empreendimento, em que haja sistema de locação das frações de tempo, por meio de uma administração única, repartindo entre si as receitas das locações, independentemente da efetiva ocupação de cada unidade autônoma, poderá a convenção do condomínio edilício estabelecer que em caso de inadimplência: o inadimplente fique proibido de utilizar o imóvel até a integral quitação da dívida; a fração de tempo do inadimplente passe a integrar o pool da administradora; a administradora do sistema de locação fique automaticamente munida de poderes e obrigada a, por conta e ordem do inadimplente, utilizar a integralidade dos valores líquidos a que o inadimplente tiver direito para amortizar suas dívidas condominiais, seja do condomínio edilício, seja do

54 TEPEDINO, Gustavo. A multipropriedade e a retomada do mercado imobiliário. Disponível em <https:/www.conjur.com.br/2019-jan-30/tepedino-multipropriedade-retomada-mercado-imobiliario>. Acesso em 31 jan. 2019. 
condomínio em multipropriedade, até sua integral quitação, devendo eventual saldo ser imediatamente repassado ao multiproprietário ${ }^{55}$.

Tepedino entende que a adjudicação é drástica e complementa:

Tal medida temporária, que caracteriza uma espécie de anticrese legal, perdurará "até a quitação integral da dívida", proibindo-se ao multiproprietário a utilização do imóvel enquanto persistir a inadimplência. Tal providência, bastante drástica, terá que ser regulada na convenção, assegurando-se o amplo direito de defesa de cada titular, podendo o condomínio inserir a respectiva unidade no pool hoteleiro, desde que haja previsão, nos termos da convenção, de tal destinação econômica ${ }^{56}$.

Seguindo essa linha, se o multiproprietário estiver inadimplente e o imóvel sujeito a um regime de pool, poderá ele ser proibido de usar sua unidade periódica, até que a dívida seja quitada, por meio da exploração de sua fração temporal. Vale dizer que deve ser considerado o lucro líquido obtido para o pagamento da dívida (art. 1.358-S, parágrafo único, do CC).

O dispositivo prevê, portanto, a anticrese ${ }^{57}$ legal da unidade periódica para o pagamento das contribuições condominiais, que deve ser interpretada com cautela, pois, deve ser precedida de um procedimento em que envolva notificação prévia do multiproprietário inadimplente para: purgar a mora por aplicação analógica do art. 404 do CC ou apresentar defesa com direito a recurso por aplicação analógica do art. 56 do $\mathrm{CC}^{58}$.

Fato é que tal providência não pode ocorrer sem aviso prévio, sob pena de violação ao princípios do contraditório e ampla defesa.

\subsection{A POSSIBILIDADE DE INCIDÊNCIA DE GRAVAMES NA UNI- DADE PERIÓDICA}

Aspecto não menos importante é a possibilidade de incidência de gravames sobre o bem imóvel objeto de multipropriedade, e a forma de sua execução.

55 BRASIL. Lei $\mathrm{n}^{\circ}$ 13.777, de 20 de dezembro de 2018. Altera as Leis nos 10.406 , de 10 de janeiro de 2002 (Código Civil), e 6.015, de 31 de dezembro de 1973 (Lei dos Registros Públicos), para dispor sobre o regime jurídico da multipropriedade e seu registro. Publicada DJE de 21/12/2018. Disponível em: < http://www.planalto.gov.br/ccivil_03/_Ato2015-2018/2018/Lei/ L13777.htm>. Acesso em 31 jan. 2019.

56 TEPEDINO, Gustavo. A multipropriedade e a retomada do mercado imobiliário. Disponível em <https:/www.conjur.com.br/2019-jan-30/tepedino-multipropriedade-retomada-mercado-imobiliario>. Acesso em 31 jan. 2019.

57 Por meio da anticrese, pode o devedor ou outrem por ele, com a entrega do imóvel ao credor, cederlhe o direito de perceber, em compensação da dívida, os frutos e rendimentos (art. 1.506) 96. A dinâmica deste direito é simples: o devedor anticrético transfere a posse do imóvel ao seu respectivo credor para que este aufira os seus frutos. GAGLIANO Pablo Stolze, PAMPLONA FILHO. Rodolfo. Manual de Direito Civil. Vol único. São Paulo: Saraiva, 2016.

58 OLIVEIRA, Carlos Eduardo Elias de. Considerações sobre a recente Lei da Multipropriedade ou da Time Sharing (Lei $\mathbf{n}^{\mathbf{0}} \mathbf{1 3 . 7 7 7 / 2 0 1 8 )}$. Disponível em < https://infographya.com/files/lei-multipropriedade-IRIB-artigo.pdf>. Acesso em 31 jan. 2019. 
Considerando ser a multipropriedade enquadrada no rol dos direitos reais, é legítima a incidência de gravame sobre a coisa, desde que o ônus incida apenas na quota-parte do devedor multiproprietário, sob pena de violação do direito de propriedade dos demais cotitulares, disposto no art. $5^{\circ}$, XXII, da Constituição da República de $1988^{59}$.

Conclui-se, portanto, que é admissível a incidência de gravames no bem compartilhado, nos limites da fração do executado.

Por consequência, a Terceira Turma do Superior Tribunal de Justiça, no julgamento do REsp 1.526.125, reconheceu que, no caso de penhora do imóvel objeto de compartilhamento espaço-temporal, o multiproprietário tem nos Embargos de Terceiro, o instrumento judicial protetivo de sua fração ideal do bem constrito.

\section{CONCLUSÃO}

A multipropriedade pode ser apresentada como uma solução para os tempos atuais de crise econômica mundial, em que as pessoas optam pela aquisição compartilhada da propriedade, por não dispor de muitos recursos para investir.

Fruto da autonomia privada, o instituto vinha sendo aplicado no Brasil, no entanto, gerando resistência e insegurança jurídica, em face daqueles que não reconheciam natureza real à avença, por ausência de regulamentação legislativa.

Assim, com o objetivo de dinamizar do direito de propriedade e extirpar a insegurança jurídica que girava em torno do instituto, em 20 dezembro de 2018, foi promulgada a Lei 13.777, que regulamenta a multipropriedade imobiliária, dando nova redação ao artigo 1.358 do Código Civil e aos artigos 176 e 178 da Lei 6.015/73, a Lei de Registros Públicos.

O modelo de propriedade compartilhada permite o acesso a empreendimentos de grande porte, sem alto custo financeiro, destinando-se, principalmente, ao público interessado em manter uma casa de veraneio sem arcar sozinho com os custos pós-compra: manutenção, segurança, impostos. Estes imóveis - casas ou apartamentos em condomínios ou resorts, com acesso a praia ou parque aquático - possuem alguns serviços de hotelaria e a unidade autônoma é fracionada entre os donos.

Em outros termos, trata-se de modelo de compartilhamento de propriedade no tempo e não apenas no espaço, que alavanca a economia do país, permitindo, num só ato, que pessoas de classes menos abastadas realizem o sonho de aquisição de um imóvel de alto valor, com investimento de menor custo.

59 BRASIL. Superior Tribunal de Justiça. RE n. 1.546.165-SP/2014 - Voto Vencedor do Ministro João Otávio de Noronha. Disponível em: <http://www.portaldori.com.br/wp-content/uploads/2016/09/AC\%C3\%93RD\%C3\%83O-NOTICIA-SEXTA-23.09.pdf>. Acesso em 29 jan. 2019. 
Por outro lado, viabilizam empreendimentos de alto investimento, como flats e hotéis, beneficiando o turismo interno e conferindo dinamismo aos empreendimentos imobiliários, pela manutenção de investimentos diversificados e fragmentados no setor.

Buscou-se, nesse estudo, apresentar o conceito, a origem e as peculiaridades da multipropriedade, demonstrando a sua natureza real e os efeitos jurídicos do compartilhamento imobiliário.

A lei em comento, portanto, é um marco importante para o mercado imobiliário brasileiro, sendo estas apenas as primeiras linhas que objetivam clarear a sua interpretação.

\section{REFERÊNCIAS}

ADROUGUE, Manuel. El derecho de propiedad en La actualidad. Buenos Aires: Aleledo-Perrot, 1991.

BARROSO, Luís Roberto. Interpretação e aplicação da Constituição. 6. ed. São Paulo: Saraiva, 2006.

BERCOVICI, Gilberto. A função social da propriedade, constituição econômica e desenvolvimento, uma leitura a partir da Constituição de 1988. São Paulo: Malheiros, 2005.

BRASIL. Lei $\mathrm{n}^{\circ} 4.591$, de 16 de dezembro de 1964. Dispõe sobre o condomínio em edificações e as incorporações imobiliárias. Brasília. Publicado Diário Oficial da União em 21.12.1964 e retificado no DOU de 1.2.1965.

BRASIL. Lei n ${ }^{\circ} 10.406$, de 10 de janeiro de 2002. Institui o Código Civil. Brasília. Publicado Diário Oficial da União em 11.1.2002.

BRASIL. Lei $\mathrm{n}^{\circ} 13.777$, de 20 de dezembro de 2018. Altera as Leis $\mathrm{n}^{\text {os }} 10.406$, de 10 de janeiro de 2002 (Código Civil), e 6.015, de 31 de dezembro de 1973 (Lei dos Registros Públicos), para dispor sobre o regime jurídico da multipropriedade e seu registro. Publicada DJE de 21/12/2018. Disponível em: < http://www.planalto. gov.br/ccivil_03/_Ato2015-2018/2018/Lei/L13777.htm>.Acesso em 23 jan. 2019.

BRASIL. Superior Tribunal de Justiça. REsp 1.526.125. Disponível em: <https:// stj.jusbrasil.com.br/jurisprudencia/574626006/recurso-especial-resp-1526125sp-2015-0074967-9/inteiro-teor-574626016? ref=juris-tabs>. Acesso em 31 jan. 2019.

BRASIL. Superior Tribunal de Justiça. RE n. 1.546.165-SP/2014 - Voto Vencedor do Ministro João Otávio de Noronha. Disponível em: <http://www.portaldori. com.br/wp-content/uploads/2016/09/AC\%C3\%93RD\%C3\% 83O-NOTICIASEXTA-23.09.pdf>. Acesso em 29 jan. 2019.

BRASIL. Superior Tribunal de Justiça. RE n. 1.546.165-SP/2014 - Voto Vencido do Ministro Ricardo Villas Bôas Cueva. Disponível em: <http://www.portaldori. 
com.br/wp-content/uploads/2016/09/AC\%C3\%93RD\%C3\%83O-NOTICIASEXTA-23.09.pdf>. Acesso em 29 jan. 2019.

BRASIL. . Superior Tribunal de Justiça. Terceira Turma reconhece multipropriedade como direito real e afasta penhora. Disponível em: <https://stj.jusbrasil.com.br/ noticias/386289514/terceira-turma-reconhece-multipropriedade-como-direitoreal-e-afasta-penhora>. Acesso em 30 jan. 2019.

CANOTILHO, José Joaquim Gomes. Direito Constitucional. 6. ed. rev. Coimbra: Livraria, 1995.

CARREIRA, Ana Luiza; LIMA, João Paulo dos Anjos; RIBEIRO, Recielly Bruna Aquino Ribeiro. Multipropriedade Imobiliária. Disponível em < https://jplima3. jusbrasil.com.br/artigos/374405475/multipropriedade-imobiliaria>. Acesso em 31 jan 2019.

CHALHUB, Melhim Namem. Multipropriedade - Uma Abordagem à Luz do Recurso Especial 1.546.165-SP. Revista de Direito Imobiliário, São Paulo, n. 82/17, p. 71-86, jan/jun. 2017.

CHAMOUN, Ebert. Instituições de Direito Romano. 3. ed. Rio de Janeiro: Forense, 1957.

COSTA, Cássia Celina Paulo Moreira da. A Constitucionalização do Direito de Propriedade Privada. Rio de Janeiro: América Jurídica, 2003.

COULANGES, Fustel de. A cidade Antiga. São Paulo: Edameris, 1966, v.1.

DI PIETRO, Maria Sylvia Zanella. Servidão administrativa. São Paulo: Revista dos Tribunais, 1978.

FERNANDES, Edésio. A nova ordem jurídico-urbanística do Brasil. Minas Gerais: Del Rey, 2006.

FRANZONI, Denise Paulus de Campos. Público e Privado: Divisão, Dicotomia e realidade.

OLIVEIRA, Álvaro Borges de \& PASOLD, César Luiz. Teoria Jurídica das Relações Interpessoais. Florianópolis: Momento Atual, 2004.

GAGLIANO Pablo Stolze, PAMPLONA FILHO. Rodolfo. Manual de Direito Civil. Vol único. São Paulo: Saraiva, 2016.

GOMES, Laurentino. 1808. São Paulo: Planeta, 2007.

GROSSI, Paolo. La propriedad y las propriedades: um Análisis histórico. Madrid: Editorial Civitas, 1992.

$\mathrm{KICH}$, Bruno Canísio. A propriedade na ordem jurídica econômica e ideológica. Porto Alegre: Sergio Antonio Fabris Editor, 2004.

LOCKE, John. Segundo Tratado sobre o Governo. Trad. Alex Martins. São Paulo: Editora Martin Claret, 2002. 
LOUREIRO, Francisco Eduardo. A propriedade como relação jurídica complexa. Rio de Janeiro: Renovar, 2003.

MARGARIDA, Mônica Paula. Fractional X Timesharing. Disponível em: < http:// revista.turismocompartilhado.com.br/2018/06/25/fractional-x-timesharing-e-ausufruicao-da-propriedade-por-monica-paula-margarida/>. Acesso em 28 jan. 2019.

MELLO, Leonel Itaussu Almeida. John Locke e o individualismo liberal. In: WEFFORT, Francisco. Os clássicos da Política. 12. ed. São Paulo: Ática, 1986.

MELO, Marcelo Augusto Santana de. Multipropriedade Imobiliária. Disponível em: < http://www.anoreg.org.br/index.php?option=com_content\&view=artic le\&id=27589:multipropriedade-imobiliaria-por-marcelo-augusto-santana-demelo\&catid=32\&Itemid=181>. Acesso em 30 jan. 2019.

MELO, Marcelo Augusto Santana de. Multipropriedade Imobiliária. Revista de Direito Imobiliário, ano 34, v. 70. p. 19-81. jan.-jun./2011, p. 2.

MESQUITA, Henrique. Uma nova figura real: o direito de habitação periódica, in: Revista de Direito e Economia. Universidade de Coimbra, 1982. p. 1: 39-69.

MIRANDA, Jorge. Manual de direito constitucional. Direitos fundamentais. Coimbra: Coimbra, 2000. tomo IV, v. 3.

OLIVEIRA, Carlos Eduardo Elias de. Considerações sobre a recente Lei da Multipropriedade ou da Time Sharing (Lei no 13.777/2018). Disponível em < https://infographya.com/files/lei-multipropriedade-IRIB-artigo.pdf $>$. Acesso em 31 jan. 2019.

PEREIRA, Caio Mário da Silva. Instituições de Direito Civil. Volume III. Rio de Janeiro: Forense. 2003.

RENNER, Karl. The institutions of private law and their Social Functions. (Trad. Agnes Schwarzchild). Routledge \& Kegan Paul, London: 1949. p. 75.

REZENDE, Afonso Celso F. Multipropriedade Imobiliária. Disponível em: http:// www.escritorioonline.com/webnews/noticia.php?id_noticia $=1308 \&$, acessado em 12 de jan. 2019.

RIBEIRO, Renato Janine. Hobbes: o medo e a esperança. In: WEFFORT, Francisco C. Os clássicos da Política. 12. ed. São Paulo: Ática, 1986. p. 53.

ROCHA, Maria Vital da. Traços da função ambiental da propriedade privada no direito brasileira, p. 119-136. In: Propriedade e meio ambiente: da inconciliação à convergência. MATIAS, João Luís Nogueira. WACHOWICZ, Marcos. (org.) Florianópolis: Fundação Boiteux, 2011, p. 119.

SCHMITT, Carl. Teoria de la Constitución. Madrid: Alianza Editorial, 1996.

SERPA LOPES, Miguel Maria. Curso de Direito Civil. v. VI. Rio de Janeiro: Freitas Bastos, 1960. 
SILVA FILHO, Elvino. Questões de Condomínio no Registro de Imóveis. São Paulo: Editora Malheiros, 1999, p. 139.

SILVA, José Afonso da. A dignidade da pessoa humana como valor supremo da democracia. Revista de Direito Administrativo. vol. 212, abr/jun, 1998.

SILVA, José Afonso da. Comentário contextual à Constituição. 3. ed. São Paulo: Malheiros, 2007. p. 117.

SOARES, Vivian Bacaro Nunes Soares. O Direito de Propriedade: Caracterização na Concepção de Autores Clássicos e Contemporâneos e Breves Comentários acerca da Função Social. Disponível em: < https://www.diritto.it/pdf_ archive/21748.pdf>. Acesso em 21 jan. 2019.

TEPEDINO Gustavo; SCHREIBER Anderson. A Garantia da Propriedade no Direito Brasileiro. Revista da Faculdade de Direito de Campos, Ano VI, $\mathrm{n}^{\circ} 6$ Junho de 2005.

TEPEDINO, Gustavo. A multipropriedade e a retomada do mercado imobiliário. Disponível em <https://www.conjur.com.br/2019-jan-30/tepedinomultipropriedade-retomada-mercado-imobiliario>. Acesso em 31 jan. 2019.

TEPEDINO. Gustavo. Multipropriedade imobiliária, São Paulo: Saraiva, 1993.

THE FLÓRIDA SENATE. 2015 Florida Statutes, Title XL Real and Personal Property, Chapter 721.05. Disponível em: <https://www.flsenate.gov/Laws/ Statutes/2015/721.05>. Acesso em 30 jan. 2019.

WALD, Arnold. Novas Dimensões do Direito de Propriedade. São Paulo: Revista dos Tribunais. 1991, v.665, ano 80.

Recebido em: 30/04/2019.

Aprovado em: 06/09/2019. 